\title{
TEORETIESE BENADERINGS VAN DIE LETTERKUNDE IN DIE JARE TAGTIG*
}

In 'n onlangse uitgawe van die bekende tydskrif New Lilerary History (Volume XIV, Herfs 1982), word meer as 200 bladsye gewy aan die probleme rondom literêre betekenis ("meaning"). Ná 'n lees daarvan dring die besef deur dat in veel gevalle verby mekaar gepraat is, nieteenstaande die feit dat al die bydraers uit dieselfde paradigma redeneer. ${ }^{1}$ Die rede hiervoor is myns insiens die feit dat daar telkens gepraat word uit 'n sekere hoek, 'n bepaalde benaderingswyse staan telkens voorop en van die spreekwoordelike tafel as studie-objek word soms 'n poot belig, soms twee, maar selde word die hele tafel in die lig geplaas. In die hieropvolgende opmerkings gaan ek doelbewus nie probeer om een afgeronde literêre benaderingswyse aan u voor te hou as die alfa en die omega nie, maar op enigsins eklekt iese wyse liefs aspekte van teorieê bespreek wat relevant mag wees vir die literatuurstudie vandag. Weens die tydsbeperking kan daar nie veel by détail-analises van literêre tekste stilgestaan word nie. Dit sê ek pertinent, want 'n teorie is vir my alleen sinvol as dit die ondersoeker in staat stel om 'n beter greep te kry op die hele literêre kommunikasie-proses, waarvan die teks ' $n$ of selfs dié belangrikste onderdeel uitmaak. ${ }^{2}$

Daar is ook 'n paar ander voorveronderstellings onderliggend aan hierdie inleidende opmerkinge:

- Die literatuur van die jare T'agtig is kwalik alleen sinvol te benader deur teoretiese uitgangspunte wat al baard het. Resenter teorieë het egter moontlik die nadeel dat hulle metodologies nog nie heeltemal deurtrap is nie én hulself nog nie voldoende in die praktyk bewys het nic.

- I cesing voor die Vakgroep Lelterkunde van die PU vir CHO op 18 April 1983 -verwerking van 'n lesing oor dieselfde onderwerp wat in (Oktober 1982 in die simposium S.A. letterkundenavorsing aan die begin van die jare lagtig van SENSAl. by UNISA gehou is.

1 Vgl. p. 175: "... and this debate cannot be resolved because what is at stake is a contest between the dillerent theoretical frameworks within which each group conceptualizes language, subjectivity and the world" (Catherine Belsey, 1982).

" In die artikel "I.A. Richards and the audit of meaning" New Literary Histury XVI: 1 haal Ann E. Berthofl vir Richards aan waar hy se dat sy studies dikwels teoreties is, maar "only that they might be practical". Soos Berthoff later self sê: "But of course the chief justification for theory is that it provides the information sources (and thus the method) for the practitioner". 
- Uit hoofde van my taak as dosent, sou ek my onderwerp ook graag só wou formuleer dat die begrip "navorsing" wyd geinterpreteer kon word as 'n wetenskaplike akı iwiteit wat nie los te sien is van die onderrigsituasie nie. Die teoretiese benaderings wat ek aan u gaan voorhou, kan myns insiens bevrugtend werk op en doelmatig benut word in 'n didaktiese situasie.

- Ten laaste: al die hieropvolgende opmerkinge het 'n enigsins subjekliewe basis omdat enige definisie van die begrip literêr slegs 'n hipotetiese status kan hè.

Die verhouding tussen die kennende subjek en die te kenne objek is sentraal in dic literatuurwetenskap. Een van die belangrikste vrac vandag is juis wat die luidige objek van die literatuurwetenskap is. In die afgelope honderd jaar was die verhouding tussen ondersoeker en teks 'n wisselende verhouding waarin drie fases onderskei kan word:

(a) die teks word gesien as dokument;

(b) die teks word gesien as monument;

(c) die teks word gesien as teken.

\section{(a) Die leks-as-dokumenl}

Die "dokument"-tcorie pas in dic algemeen-filosoficse kader van die positivisme en dit kan geplaas word ongeveer in dic tweede helfte van die Negentiende eeu. Die artisticke komponent van hierdie deterministiese filosofie is die naturalisme waar die mens dikwels gereduscer word tot slagoffer van milicu en erllikheid. In die positivisme kry ons die socktog na wetmatighede op grond waarvan sekere voorspellings gewaag kan word. Hierdie soektogte ont aard dikwels in 'n maklike oorstap van werk na outeur óf andersyds vanuit die outeur tot 'n rekonstruksie of verklaring van sy werk. Die positivistiese standpunt dat dic teks gesien kan word as dokument is langsamerhand al ou nuus, óók die invloed wat dit op (Suid-) Afrikaanse literatore gehad het. Gocie besprekings hiervan is onder andere Rialctte Wiehahn se gepubliseerde procfskrif Die Afrikaanse poësiekritiek en die recks artikels van haar promotor, N.P. van Wyk Louw, "Die mens-agter-dieboek". Hierdic benaderingswyse is skynbaar dood en begrawe, maar duik in feite sporadies op in enige beskouing waarin die teks ondergeskik gemaak word aan (wetmatighedc) buite hom om: omdat $\mathrm{X}$ leef in situasie $\mathrm{Y}$ sal/behoort hy só 'n werk te lewer.

\section{(b) Die teks-as-monument}

Die sogenaamde hermeneutiek is 'n reaksic op die positivisme en veral tcen 
die splitsing subjek-objek. Objek en subjek "versmelt" op 'n gelukkige monument van ontmoeting. Dit kan slegs gebeur as die subjek hom verwant voel met sy objek en dit van waarde ag. Hoewel uitstekende interpretasies die resultaat van hierdie benaderingswyse was, kan die beswaar geopper word dat intersubjektiwiteit uitgeskakel word deur o.a. die persoonlike taalgebruik en dat wetenskap eintlik só bedrywe kan word.

Die hele groep outonomistiese bewegings van die vroeë en middel Twintigste eeu kan nie sondermeer direk in verband gebring word met die sg. hermeneutiek nie. Daar bestaan egter een groot ooreenkoms: die klemplasing op "monumentale" werke wat dikwels bestudeer word as ewige monumente van skoonheid: "waar vleklose skoonheid is, is daar geen oorsaaklikheid nie" (Staiger).

Bakens op hierdie "outonomistiese" pad is eerstens die Russiese formaliste, wat die outonomiteit van die kunswerk beklemtoon. Verder die sogenaamde New Critics wat deur hul hekeling van die talle "fallacies" of dwalinge van vroeër metodes, beklemtoon dat 'n literêre werk bestaan onathanklik van sy maker, tyd van ontstaan, ens. T'en laaste die SuidAfrikaanse pendant van die outonomistiese bewegings: die linguistiek op stilistiese grondslag. Dit is 'n beweging wat skool gemaak het en 'n belangrike invloed uitgeoefen het op Suid-Afrikaanse letterkundenavorsing en -onderrig, veral aan Afrikaanse Universiteite.

\section{(c) Die leks-as-leken}

Hierdie benadering bestudeer die verhouding van die teks tot die sender, ont vanger en buitetalige werklikheid. Die grondslae van hierdie benadering is gelê deur een van die Praagse Strukturaliste, Jan Mukarovský (18911975). Die kunswerk kan nie gelykgestel word aan die materiële aspek daarvan naamlik die artefakt nie, want die artefakt verkry eers beteken is wanneer dit deur'n ont vanger omskep word tot 'n estetiese objek (Fokkema en Kunne - Ibsch 1977:31).

Mukarovský beweer dat die estetiese potensiaal nie 'n inherente eienskap van 'n objek is nie hoewel sekere objekte 'n groter potensiaal bevat. Enige objek kan dit verwerf.

Die historiese komponent is ingebou in sy omskrywing van die estetiese funksie, want orals en altyd speel $\ell$ d, plek en beoordelaar' 'n rol. Wat wel gebeur, is dat daar 'n stabilisering plaasvind van estetiese lunksies in 'n maatskaplike afspraak en sosiale konteks. So ken ons nou byvoorbeeld 'n estetiese funksie toe aan 'n objek (bv. 'n geelhouttafel) wat vrocër 'n 
prakt iese funksie gehad het. Dit is veral in die kuns waar die estetiese funksie 'n rol speel en juis daarom val ander funksies (bv. 'n politieke) sterk op in kunswerke.

Deur sy estetiese funksie, beweer Mukarovský, kry 'n objek 'n sekere vervreemding van die werklikheid en verwerf outonomie. 'n Mens kan dus samevattend sĉ: in 'n maatskappy bestaan informele afsprake oor wat literêr is. Literêre norme is weliswaar veranderlik, maar die estetiese funksie staan in direkte verhouding tot sekere norme. Vanweë die feit dat 'n objek 'n ander funksie het, word 'n ander waarde daaraan geheg en moet dit aan sekere norme voldoen. Dit impliseer ook dat in die Simbolisme byvoorbeeld ander norme geld as in die Romantiek. Mukarovský wys daarop dat die artefakl onveranderlik is, maar dat die estetiese objek (dit is dic realisasie van die artefakt) veranderlik is. Met ander woorde: 'n literêre werk is vasgelê in skriftekens en die artefakt sal dus dieselfde wees in 1930 of 1980. Dit word egter eers 'n estetiese objek as dit deur 'n leser gerealiseer word, en die 1930-realisasie sal verskil van dié in 1980 onder andere as gevolg van ander norme.

Ook Jury Lotman, die Russiese semiotikus, plaas 'n hoë premie op die ontranger van 'n artefakl. Die ontvanger moet die talige boodskap dekndeer, hy moet dus op die hoogte wees van die taal-én literêre kode van die bepaalde boodskap ten einde die werk te interpreteer. 'n Teks word sodoende altyd in konteks geplaas en die tekens daarin kan slegs geïnterpreteer word in verhouding tot ander teks- en tckensisteme. So ' $n$ benadering is 'n radikale ommekeer van die outonomistiese standpunt.

\section{DIE NUWE PARADIGMA}

Literatuurwetenskaplikes praat al vroeg in die sewentigerjare van die sogenaamde "nuwe paradigma", wat dan sou dui op 'n totale nuwe teoretiese benadering in die literatuurwetenskap. Hierdie stelling kan in sy absoluutheid betwyfel word, omdat daar nie so fundamenteel gebreck word met vroeëre benaderingswyses nie: I. $\Lambda$. Richards ${ }^{3}$ en Mukarovský is al vrocë wegbereiders van die Resepsic-estetika, die Semiotiek gaan terug op insigte van Peirce en De Saussure en die moderne Psigo-analiste is in hoë mate skatpligtig aan Freud (1856-1939). ${ }^{4}$

3 Berthofl. Ibid., p. 186 wys ook daarop dat Richards recds in 'n vroeë stadlium blyke ger van 'n semiotiese werkwyse.

- Die artikels oor 'n psigo-analitiese benaderingswyse in die aangrhaalde uitgawe van. Nere Literary /fistory is hiervan 'n speckende hewys. 
Een van die belangrikste kenmerke van hierdie nuwe paradigma is 'n gewysigde opvatting van die objek van die literatuurwetenskap - die objek is nie meer alleen die teks nie, maar die literêre kommunikasie-situasie. Tog bly die teks objek van die literatuurwetenskap "mits gerelateerd aan de literaire communicatiesituatie en opgevat als een produk van codering dat om dekodering vraagt" (Fokkema 1981:190). Die literêre kommunikasieproses bestaan uit drie komponente:

$$
\text { sender } \quad-\rightarrow \text { (boodskap) } ४--\quad \text { - - zontvanger }
$$

'n Sender (skrywer) enkodeer 'n boodskap (teks) wat gerig word aan 'n potensiële ontuanger of geadresseerde (die leser) wat die teks (die kode) moet realiseer (dekodeer). Eers dan word hy die werklike ontvanger. Uiteraard is hierdie proses veel ingewikkelder as wat ek hier kan aandui. Die ontvanger is, soos reeds gesê, geen konstante nie. Die boodskap is, net soos die sender, ingebed in 'n komplekse konteks: literêr, sosiaal, histories, ensovoorts. Uiteraard sal hierdie verskillende "resepsies" van 'n boodskap (teks) nuttige informasie kan verskaf oor én teks én die tydperk van resepsie. Vroeëre literêre tydperke kan byvoorbeeld sodoende gerekonstrueer word.

Ek kan vervolgens 'n paar resente benaderingswyses wat op een of meer van hierdie komponente konsentreer, nader toelig.

\section{A. IDIE SENDER}

Jurÿ Lotman het beweer dat 'n ontvanger van 'n lit erêre teks nie alleen die taal (d.i. linguistiese kode) moet ken nie, hy moet ook bekend wees met die literêre kode. Indien die literêre kode onbekend is, sal die ontvanger probleme hê om die teks te interpreteer of sells as 'n literêre teks te herken. Wanneer 'n teks byvoorbeeld twee sub-kodes bevat (bv. Romantiek en Realisme) word dit moeiliker om te dekodeer (Fokkema en Kunne-Ibsch 1977:43). Wanneer sender en ontvanger tot verskillende kultuurgebiede en/of historiese tydperke behoort, kan probleme ontstaan omdat dic ideaal is dat die senderskode ten volle bekend moet wees.

Die sender kry vandag weer sy regmatige aandeel in die literêre kommunikasieproses en die sogenaamde "senderskode" word gerekonstrueer aan die hand van veral ander teoretiese en persoonlike geskrifte deur die sender. D.W. Fokkema se rekonstruksie van Virginia Woolf se senderskode in sy bespreking van $T_{0}$ the lighthouse (1980) is 'n goeie voorbeeld van hierdie aanpak. In hierdie artikel gaan Fokkema uit van die veronderstelling dat Virginia Woolf se werk To the lighthouse tuishoort binne die modernistiese kode. Fokkema rekonstrueer dan die senderskode op grond van drie ander 
fiksionele geskrifte van Virginia Woolf, waardeur 'n hele periode leitlik herskep word maar dan met spesifieke konsent rasie op Virginia Woolf se eie subkode. In die proses word ook gebruik gemaak van briewe en dagboeke van dié "konkrete" outeur.

Fokkema lê groot klem op seleksie- en kombinasieprinsipes in die teks wat as 't ware as kontrole dien ten einde die sogenaamde "intentional fallacy" te vermy.

Oor Fokkema se metode kan daar geredekawel word. Sy stappe in die proses van interpretasie bevat egter waardevolle riglyne ten einde 'n interpretasie kontroleerbaar te maak. Hy gaan daarvan uit dat én die kode van die oorspronklike teks én die kode van die interpretasie gespesifiseer moet word. 'n Ondersoeker moet:

1. die kodes van die teks onderskei;

2. die boodskap dekodeer in terme van die kodes waarop hy besluit het;

3. die kode bepaal wat as metataal sal dien vir sy interpretasie (bv. semiotiese, narratologiese, ens.);

4. sy bevindinge enkodeer in hierdie meer toeganklike kode sodat 'n nuwe boodskap geproduseer word. Hierdie nuwe boodskap (die interpretasie) is 'n "vertaling" van die oorspronklike teks.

Sonder om Fokkema woorde in die mond te lê, kan algelei word dat hy daarvan uitgaan dat ' $n$ teks sekere betekenisse dra wat sentraler is ten opsigte van die tekskode as ander. Interpretasies kan derhalwe gegradeer word. Fokkema se metode is Popperiaans, want sy hipotese ten aansien van To the lighthouse word aan die hand van teksgegewens getoets.

Wanneer die korrektheid al dan nie van 'n interpretasie bespreck word, sê Fokkema, moet daar ooreenstemming (of ten minste aanvaarding) wees van die kode wat gebruik gaan word vir dekodering van die teks. Die aanpak van Fokkema is histories (nie historisties nie) omdat 'n periodekode 'n konstruksie agteral is wat afgedruk word op 'n sekere tydperk.

Fokkema se metode is ook anti-outonomisties omdat die teks onder bespreking, byvoorbeeld To the lighthouse, voortdurend gerelateer word aan ander tekste van dieselfde outeur. Daar het in die loop van 198I talle studies oor Van Bruggen die lig gesien waarin hy om die beurt as realis, naturalis, idealis, ensovoorts beskryf word. Miskien sou dit die moeite loon om Fokkema se metode toe te pas op 'n ouer Afrikaanse outeur. Dit sou in ieder geval die interpretasies kontroleerbaar maak, wat die wetenskaplike gesprek tot voordeel strek. 


\section{B. DIE TEKS}

Nuwe benaderings wat primêr op die teks konsentreer, Inaar dan altyd as onderdeel van die hele literêre kommunikasie-proses, is die rigting wat breedweg aangedui kan word as Intertekstualiteit en dan verskeie benaderings wat 'n mens sou kon noem:

\section{Sermiotiese benaderings}

(i) Die begrip intertekstualiteit wat gebaseer is op die werk van Julia Kristeva en Jacques Derrida: Vir hulle setel die betekenis van tekste in die verskil en ooreenkoms met ' $n$ ander teks. Tekste kom voort uit tekste en sou beskou moet word binne 'n tekstuele domein. Intertekstualiteit is dus die begrip dat 'n teks onherroeplik beinvloed is deur ander tekste. Die aanduiding van ander tekste se werking binne 'n gegewe teks, die "afbreek" van 'n teks' ("dekonstruksie") in ander teks-elemente het as metode nog dikwels iets tc persoonliks, berus te veel op die ideosinkratiese kennis, om algemeen oordraagbaar te wees as metode (bv. Van Boheemen 1981).

'n Poging om 'n model daar te stel word bv. gedoen deur Meir Sternberg in sy artikel in die jongste Poetics Today. Sternberg ontleed bv. die verskillende mimetiese verhoudings tussen tekste waar aanhalings uit die oorspronklike konteks ingebed word in 'n nuwe konteks, m.a.w. die intertekstuele samehang wat só ontstaan.

(ii) Die semiot iek het te make met alles wat as teken aanvaar kan word. Die bron wat 'n sekere sinjaal versend, hoel nie menslik te wees nie, maar die ontvanger moet, want iets word eers as teken gesien deur 'n interpretatiewe reaksie gegrond op 'n bestaande kode. Met ander woorde "signifikasie" vind plaas wanneer die ontvanger iets wat aan hom gebied word as teken interpreteer, en teken beteken: in die plek staan van iets anders. 'n Verdere gevolgtrekking is dat nie elke ontvanger noodwendig so sal reageer nie, maar dat die moontlikheid wel bestaan.

Die semiotiek of tekenleer gaan uit van die veronderstelling dat die literêre teks 'n teken is wat in die plek staan van iets anders, naamlik die fiksionele werklikheid. Die literêre teks bevat egter ook talle klciner tekens, talig sowel as nie-talig. Uiteraard is dit die taak van die leser om die tekens as sodanig op te val, want semiosis is die proses van transmissie van betekenis van bron na ontvanger.

Die teken staan in 'n drievoudige verhouding en wel tot sy ground, sy »bjek en sy interpretant. Van Zoest (1978: 104) noem as voorbeeld die woord tafel. Die 
woord verwys na 'n cling (objek): die ground is die Nederlandse (of Afrikaanse) taal en die interpretant dit wat ons in 'n Woordeboek kan lees. In die teken-objek-verhouding onderskei Van Zoest drie moontlikhede. Die verhouding kan een van gelykenis wees, die teken heet dan iknon; van aangrensendheid: inteks, van afspraak of konvensie: simbool. Die woord "lafel" hierbo is 'n voorbeeld van 'n simbool, 'n padwyser is 'n indeks, 'n portert 'n iknon.

Die begrip ikonisiteit bied ecrstens toepassingsmoontlikhede vir literatuurstudie. Daar is sprake van ikonisileit in 'n teks as daar'n gelykenis blyk te wees tussen 'n teken en sy ohjek. Feitlik alles in 'n teks kan tot teken verklaar word: die tipografie, frekwensic van adjektiewe, vertelpunt, ensovoorts. 'n Moeilike vraag is: wannecr is daar van gelykenis sprake? As die teken en sy objek identieke predikate bevat, sou 'n mens kon sê dat daar gelykenis is. Van Zoest verwys na 'n gedig van Morgenstern, "Der Trichter", wat tipografies ook op 'n tregter lyk. Sodanige ikonisiteit beskou hy egter as redundant, omdat dit niks wesenliks toevorg tot die interpretasie nie. Die strukturele siklisitcit in Die Sprinkaanbeample van Sluis is byvoorbeeld ikonies van die verstikkende uitsigloosheid van Bredenhand se eenselwige bestaan.

Nog 'n soort ikoon is melaforiese ikone waar die gelykenisverhouding nie opt ree tussen teken en objek nie, maar tussen twee objekte wat albei deur dic teken genoteer word. Metaforiese ikonisiteit doen hom voor op makrostrukturele vlak in tekste wat allegories of parabolies genoem word (Van Zoest 1978a:110). Plaston van P.G. du Plessis is hiervan 'n voorbceld. Aardendal word die wêreld en die dorpsmense die mensheid; gelykstelling kan selgs volg as die twee objekte dorp en wêreld, gelykenis met mekaar vertoon. Van Zoest se werk Semintiek over tekens, hoe ze werken en wat we ermee doen, $\triangle \mathrm{MBO} 1978$, is 'n nuttige inleiding tot hierdie gebied.

In 'n besonder helder artikel lê Eugene F. Kaelin (1982) klem op die oordraagbaarheid wat ten grondslag lê van 'n semiotiese lesing van 'n teks. Ek haal aan: "The trick (...) is to concentrate upon our immediate "significate effect ${ }^{5}$, of the text in relationship to the structures perceived to exist in relationship by virtue of the text". Hierdie strukture kan beskryf word, hetsy in gewone taal, hetsy in tegniese woordeskat. Wanneer 'n leser van hierdie tipe krit iek lsewus word van hierdie strukturele verhoudings, sal hy of sy 'n soortgelyke "significate effect", van die gestrukturcerde teken ondergaan. "Critic and reader of such criticism will then have communicated

s "'Significate eflect' of the sig" - that is, our conscious reaction to its perception as a sign, as having or communicating a message" (p. 202). 
the conditions that have determined the original reader's response to a literary text interpreted as a sign that includes both a field of interrelated signifieds and a set of sensuous signifiers" (Kaelin 1982:202). ${ }^{6}$

Uit die voorafgaande is dit duidelik dat die betekenisvolle verhoudings tussen teksgedecttes bv. deur 'n leser gerealiseer word. Charles Peirce het sodanige lesersreaksies die interpretant genoem, die derde element van die driehoekige verhouding wat nodig is om die verband tussen teken en betekende 'n objek van bewuswording te maak (Kaelin 1982:201).

\section{DIE ONTVANGER: RESEPSIESTUDIES}

Die resepsie-estetika ontstaan in die laat sestigerjare in Wes-Duitsland en verlê die klem van die teks na die leser. Hulle gevolgtrekking is dat die literêre teks nie iets ewigs en objektief is nie: wat as meesterwerk beskou word in die een tydperk kan as prul beskou word in 'n later tydperk. Hulle studie-objek is dus die estetiese objek eerder as die artefaht.

Jauss gaan uit van die standpunt dat 'n leser 'n teks lees met sy hele leescrvaring of verwaglingshorison. Die verwagtingshorison behels:

1. Die leser se kennis van die norme van die genre waaronder die werk resorteer;

2. sy kennis van en verbandlegging met ander werke uit dieselfde tydperk, en kennis van

3. die teenstelling fiksie/werklikheid oftewel die onderskeid tussen die poëtiese en die praktiese funksie van taal.

Die estetiese distansie, dit wil sê die verskil of afstand tussen die teks en die lesersverwagting, bepaal vir Jauss eerstens die estetiese waarde van 'n teks. Met ander woorde: hoe kleiner die estetiese afstand, hoe nader is dié teks aan verstrooiingsliteratuur. Ten tweede bied hierdic begrip die moontlikheid om historiese resepsies te beskryf en sodoende literêre norme te agterhaal in sy diachroniese verband.

Daar is etlike besware in te bring teen sy stellings. Segers (1979:12) wys

6 Vgl. die volgende onskrywing van Kaelin (1982:202): "I do not insist upon calling a literary work of an a 'rhematic, iconic qualisign' but that is what it is in the Pcircian classification of signs. Being a qualisign, its vehicle is a quality - the total expressiveness of the piece; being iconic, it resembles its object - an alfective state: being rhematic, its object is a possible signilicance that exists for anyone with enough patience and skill to make the connection. 'Texts are for reading. 
daarop dat volledige deurbreking van 'n verwagtingspatroon nie byvoorbeeld 'n maksimale estetiese effek oplewer nie. Boonop neem Jauss nie Lotman se onderskeid tussen 'n sogenaamde estetika van identiteit en estetika van opposisie in ag nie (Fokkema en Kunne - Ibsch 1977:45). Hiervolgens is dit duidelik dat in sekere periodes verwagtings juis nie deurbreek word nie en dat daar tog 'n estetiese effek is. Voorts is dit geen maklike taak om empiriese materiaal te vind nie - dikwels is daar in sekere tydperke haas geen geskrewe resepsies te vinde nic. 'n Uitweg is dan om 'n hipoletiese resepsie daar te stel. Hierdie beweging na die teks, kry ons ook by Jauss, wat later praat van verwagtingshorison van die teks, "de textuele verwachtingshorizon kan opgesteld worden door de in de tekst besloten lezerzrol te expliciteren": dit is die sogenaamde implisiete leser (Segers 1979:12).

Iser weer wil 'n verklaring bied vir verskillende resepsies van 'n teks. Literêre werke word volgens Iser gekenmerk deur hul vaagheid omdat 'n teks nie ooreenstem met werklike voorwerpe uit die wêreld van die leser nie. Dié vaagheid ontstaan as gevolg van sekere "oop plekke" in die teks wat invulling behoel' van 'n leser. Dié invulling geskied nie bloot intuitief nie, maar daar is sekere riglyne vir die implisiete leser. Geen wonder dat Iser die skyf van kritick geword het nie - sy opmerkinge is veel minder "demokraties" as dié van die sogenaamde empiriese ondersoekers wat alle lesers gelykstel. Laasgenoemde hou hulle besig met die reële/werklike leser en staan as ondersoekers buite die leesproses. In Het lezen van literatuur van Segers word 'n hele paar praktiese tocpassings geill ust reer, byvoorbeeld 'n ondersoek na 'n verwagt ingshorison en 'n ondersoek na waardeoordele van lesers oor moderne literatuur.

Ondersoek na die werking valı 'n teks kan in die eerste instansie ondersoek inhou na nie-bestaande ideële lesers. Teksintern vind 'n mens die onderskeid tussen die implisiete en eksplisiete leser. Die eksplisiete leser word direk of indirek aangespreck deur die fiktiewe verteller (vgl. byvoorbeeld dic eksplisiete lesersiol in De onrustzaaier van W. van Maanen); die implisiete leser is 'n lesersrol wat in die teks opgeslote is: "het geheel van tekstuele aanwijzingen bestemd voor de werkelijke lezer, die daardoor te weten komen hoe de tekst gelezen noct worden" (Segers 1980:22). Hierdie begripspaar kom baie ooreen met die abstrakle en fiktiewe leser (Schmid 1973).

By hierdie hele reeks lesers: Implisietc, eksplisiete, model, gemiddelde, geïnformeerde, ensovoorts voeg Robert Rogers sy "amazing reader" (Rogers 1982:31-46). In 'n prikkelende en uitdagende stuk trek Rogers die buitelyne van sy verbasende leser. Rogers sien sy leser as 'n empiriese persoon wat 'n leesrol vervul "he never indulges himself beyound the 
possibilities inherent in the text he reads. To do so would be a perversion of the text itself, of misinterpretation" (p. 32). Kenmerke van hierdie leser is die volgende:

1. Hy glo dat 'n sender' $n$ boodskap stuur aan 'n ontvanger,

2. Hy glo interpretasies kan getoets word "by establishing the presence of unambiguous patterns in a text and by demonstrating degrees of consensus among receivers concerning the meaning of a 'message' ( $p$. $34)$,

3. Hy glo dat die interpretatiewe proses definitief is in sommige en in ander opsigte vryer is; die verbasende leser indentifiseer daarom maklik met dinge, sit uasies, ens.

4. Hy beskik oor ' $n$ verbasende vermoë om informasie te prosesseer; hy maak soms foute en raak sy pad byster maar red hom telkens uit die doolhowe,

5. Hierdie leser nader weliswaar' 'n sluitende interpretasie, maar terselfdertyd besef hy "that analysis remains interminable to the extent that signs can only be read in terms of other signs, as C.S. Peirce tells us, in a way that confronts the reader of a poem, at least theoretically, with what Eco calls unlimited semiosis" (p. 37).

Rogers neem vervolgens 'n gedig van Wallace Stevens "The Snow Man" en probeer op grond van 'n paar lesings van empiriese, werklike lesers, die verbasende leser rekonstureer. Die verskillende interpretasies word vervolgens vergelyk deur dit te toets aan Stevens se uitsprake, deur dit onderling te vergelyk, met veral die beeldgebruik in die teks en dan met kontrast iewe interpretasies. Sy gevolgtrekking is dat betekenis nie lê in een enkele element bv. leser/skrywer/teks, ens. nie, maar in die samespel van dele en geheel: "this model of interpretation may be said to exhibit a holist ic view of the literary process" (p. 45).

'n Verdere resente ontwikkeling op hierdie gebied is die bestudering van romansupplemente. ${ }^{7}$ Lesers word verdeel in passiewe lesers: hulle maak resepsie nie openbaar nie; dit is egter sogenaamde akt iewe lesers ... wat hul resepsie verwoord. Die Ig. groep word verder verdeel in reproduserende en produkliewe lesers. Produktiewe resepsie ontstaan wanneer die resepsie van teks A lei tot nuwe literêre werk $B$; uiteraard mag skepper en navolger nie dieselfde persoon wees nie. Reproduserende resepsie het te make met analises, resensies ens., van die oorspronklike teks.

7 Die bespreking hiervan berus in hootsaak op die studiever slag (1983) van D.J. Hugo, tans besig net navorsing in I.euven. Kyk verder: Van Vonderen, José, 1981-82 : 193-211. 
Romansupplemente is 'n vorm van produktiewe resepsie - 'n aanvulling van 'n moderne prosawerk wat fragmentaries is of so voorkom.

D.J. Hugo beskryf romansupplement as volg: Dit is 'n (...) aanvulling wat' $n$ skrywer maak by 'n literêre prosawerk van 'n ander skrywer, waarin die geskiedenis van die voorbeeld vervolg word en/of hiate ingevul word en/of die voorgeskiedenis gegee word, waarby die voorbeeld onaangetas bly en waarin een of meer personasies en moontlik die plot van die verhaal oorgeneem word".

'n Ondersoek kan byvoorbeeld onderneem word na produktiewe resensies van Hettie Smit se. Sy kom met die sekelmaan ten einde vas te stel of enige van dié navolgings die vorm van 'n romansupplement aannccm.

Waar daar in die voorafgaande meer gekonsentreer is op die afsonderlike komponente van die literêre kommunikasiesituasie, wil ek afsluit met 'n pragmatiese benadering waarin al die komponente gelykberegtig word, naamlik die sogenaande "Speach Act Theory" of Taalhandelingsteoric, oorspronklik geformuleer deur J.L. Austen.

D. SPREKER - BOODSKAP - HOORDER / SENDER - BOODSKAP -ONTVANGER

'n Taalhandeling is 'n linguistiese verbintenis tussen 'n spreker (ek) en sy hoorder (jy) en kan beskryf word as 'n manier waarop 'n mens met taal kan dóén; die pater familias se snouende "sout"! het tot gevolg dat hierdie korrelrige smaakmiddel vinnig by die ewe korrelrige vader aanland. 'n Taalhandeling, nie 'n fisiese handeling nie. 'n Taalhandeling bestaan uit 'n lokusie, illokusie en perlokusie. Die lokusie, die uiting is die proses/daad. Die illokusie is wat die spreker doen deur iets te sê, die spreker se basiese semantiese bedoeling. Austen onderskei ook 'n perlokusie: "This amounts to the consequences or ellects upon the addressee, the addressee's reaction" (Campbell 1975:3). Dit lê alles ingebed in 'n koherente sistecm van gespreksvoorwaardes wat ongeveer gelyk is aan konteks en siluasie.

Vir elke soort taalhandeling is daar 'n ander stel gespreksvoore'aardes wat daarmee gepaard gaan. Bevele impliseer byvoorbeeld outoriteit, vrae is gemik op die inwin van informasie en versoeke wil 'n reaksie tot gevolg hê -fisies ól verbaal.

Dit literêre gespreksituasie is al deur ondersockers so verskillend soos W. Iser (Segers 1979:41/43) en Umberto Eco (Eco 1979:11) as 'n taalhandeling bestempel. 
Campbell beweer byvoorbeeld dat die outeur van 'n literêre werk 'n bepaalde perlokusie by sy ontvangers wil bereik, dat hy met ander woorde 'n sekere bedoeling het. Dit skep uiteraard probleme vir die literêre gespreksituasie waar outeursintensie selde kontroleerbaar te agterhaal is. Waar dit wel die geval is (soos byvoorbeeld in dagboeke, manifeste, ensovoorts), is daar geen 1:1-relasie nie. Die swakste werke is immers al met die beste bedoelings geskryf? Die taalhandelingsraamwerk is ' $n$ hoogs kontroleerbare beskrywing van betekenis-oordrag ook in literêre werke. Bedoeling is ongeveer gelyk aan illokusie, die geslaagdheid daarvan is die perlokusie en die literêre teks is die lokusie. Deur te let op die vorm van die illokusie en die gespreksvoorwaardes, sou die bedoelde perlokusie algelei kon word. Literêre gespreksvoorwaurdes het onder meer te doen met kennis van konvensies, die seleksie- en kombinasieprinsipes wat in 'n bepaalde periode dominant is, die sogenaamde periodekode. Dra die ontvanger geen kennis van byvoorbeeld die literêre norme en waardes heersend in die China van 1950 nie, kan 'n teks uit dié tyd moeilik as literatuur gelees word deur 'n Westerling, geskool in 'n ander literêre tradisie. Fokkema se rekonstruksie van die senderskode is in werklikheid die rekonstruksie van bepaalde gespreksvoorwaurdes waarsonder dié werk moeiliker kommunikeer. Op teksinterne vlak is daar uiteraard ook bepaalde gespreksvoorwaardes - dit is seker nie nodig om meer hieroor te sê in die lig van die reaksies rondom Magersfontein, o Magersfontein! nie.

In Opperman se "Edms. Bpk." kom daar bv. ook taalhandelinge voor. Die taalhandeling waardeur eiendomsreg opgeëis word, is hier 'n proklamasie wat byvoorbeeld bepaalde gespreksvoorwaardes het. Dit is 'n amptelike bekendmaking - indien van eiendomsreg, dan gebaseer op 'n wetlike koopkontrak. Dirk se tekening van sy naam berus byvoorbeeld op die feit dat hy kontraktueel die wettige eienaar is. Janfiskaal eerbiedig nie die aanvaarde gespreksvoorwaardes nie en proklameer sy besit nieteenstaande sy gebrek aan "wettige" eiendomsreg. Daardeur word geïmpliseer dat die naturdinge nie ondergeskik is aan menslike wette nie - die mens se eiendomsreg is beperk.

Die sentrale gedagte by gespreksvoering - 'n voorwaarde vir' $n$ gesprek -is die koöperatiewe beginsel. Dit is die appèl wat deur die spreker gemaak word op die hoorder(s) om saam te werk aan die gesprek. Sonder samewerking misluk die gesprek. Wanneer die sprekersrolle in N.P. van Wyk Louw se "Gesprek van die dooie siele" nader bekyk word, blyk die volgende: Wanneer die herhaalde pogings van die cerste spreker tot die stig van 'n gesprek in gedagte gehou word en daarmee die manlike spreker se weiering om as hoorder deel te neem, is dit duidelik dat "Gesprek" ironies bedoel is. Hier is in der waarheid nie sprake van twee "siele" wat 'n lewendige gesprek voer nie - hulle is "dood" ten opsigte van mekaar en wat 
lyk na 'n gesprek is veel eerder twee alleensprake - soos dic titel van dic bundel ook aandui (Van Coller en Van Rensburg 1982:225-230).

Illokusies gaan gepaard met bepaalde seggingskrag wat om interessante redes kan slaag of misluk. Indien die illokusiekrag nie slaag nie volg daar nie 'n perlokusie of, korrckter, die bedoelde perlokusie nie. Notaris Pilaar wil 'n bepaalde perlokusie tot gevolg hê van sy hoorder in De onrustzaaier (Willem van Maanen). Indien die reële leser dié reaksie deel, vervul hy nie die rol van implisiete (abstrakte) leser nie van wie 'n ander reaksie verwag word naamlik verwerping van Pilaar en sy hoorder, die fiktiewe of eksplisiete leser. Die bedoelde perlokusie kan aangetoon word deur die illokusie - verwagtinge te ondersock en dic belangrikste gespreksvoorwaardes te rekonstrueer (Van Coller 1982:237-25I).

Naomi en Asa Kasher beweer: "To understand a poem is to construct for it an appropriate context of utterence (...). An interpretation of a poem is a completion of a speech act" (Kasher 1976:77-81). Dit spreek daarom vanself dat taalhandelinge vertaal moet word en dat daar gestrewe moet word na dieselfde perlokusie-gevolg in die doeltaal. Die voordele van 'n taalhandelingsbenadering lê vir my in die besef dat die literêre teks deel vorm van 'n kommunikasieproses tussen 'n sender en ontvanger, maar ook dat daar betekenisoordrag is in hierdie proses. Die taalhandelingsbenadering is één manier om betekenisoordrag te beskryf, maar as hoogskontroleerbare beskrywing inderdaad 'n wins vir die literatuurondersocker. ${ }^{8}$

\section{BIBLIOGRAFIE}

BELSEY, CATHERINE, 1982. Problems of literary theory: The problem of meaning. Nere literary History, Vol. XIV, Herfs, nr. 1, pp. 175-182.

BER'THOFF, ANN E. 1982. I.A. Richards and the audit of meaning en Response to Catherine Belsey. New Literary History, Vol. XIV, Herfs, nr. 1, pp. 63-79 en pp. 185-186.

CAMPBELL, B.G. 1975. T'owards a workable taxonomy of illocutionary forces and its implication to works of imaginative literature. (In Language and style 8: 1.3-20).

ECO, UMBERTO, 1979. The role of the reader. Bloomington. Indiana University Press.

FOKKEMA, D.W. 1980. An interpretarion of To the lighthouse with

\footnotetext{
- 'n Voorbecld van' 'n verant woorde en kundige toepassing is M. Hancher (1980) se analise van sonnet 19 van Shakespeare.
} 
reference to the Code of Modernism. P.T.L.: Journal for Descriptive Poetics and Theory of Literature, 4, pp. 475-500.

FOKKEMA, D.W. Vergelijkende literatuurwetenschap en het nieuwe paradigma. Forum der letteren, Junie 1981, 179-194.

FOKKEMA, D.W. en KUNNE - IBSCH, ELRUD. 1977. Theories of literature in the twentieth century. London, C. Hurst en Kie.

HANCHER, MICHAEL. 1980. Understanding poetic speech acts. (In: Ching, M.L. e.a.: Linguistic perspectives on Literature, pp. 295-304. Londen. Routledge and Kegan Paul).

KAELIN, EUGENE E. 1982. The Fourteenth Way of Looking at a Blackbird. New Literary History, Vol. XIV. Herfs, nr. 1, pp. 191-203.

KASHER, NAOMI EN ASA. 1976. Speech Acts context and valuable ambiguities. (In: Van Dijk, T.A., red.: Pragmatics of language and literature. pp. 77-81. Amsterdam. Noord-Holland Uitgewers).

LOUW, N.P. VAN WYK. 1975. "Die 'mens' agter die boek". (In: Swaarteen Ligpunte (tweede uitgawe). pp. 90-140. Kaapstad. Tafelberg-uitgewers). MUKAROVSKY, JAN. 1970. Aesthet ic function, norm and value as social facts (translated from the Czech by M.E. Suino). Michigan. Ann Arbor.

ROGERS. ROBERT. 1982. Amazing Reader in the labyrinth of literature. Poetics Today, Lente, 3:2, pp. 31-46.

SCHMID, W. 1973. Der Textaufbau in den Erzählungen Dostoevskijs. München. Fink.

SEGERS, R.T. red. 1979. Receptie-esthetica; grondslagen, theorie en toepassing. Amsterdam. Huis aan de drie grachten.

SEGERS, R.T. 1980. Het lezen van literatuur. Baarn. Ambo.

STERNBERG, MEIR. 1982. Proteus in Quotation-land. Poetics Today, Lente, 3:2, pp. 107-156.

VAN BOHEEMEN, CHRISTEL. 1981. Intertekstualiteit: Een inleiding. Ongepubliseerde voorlesing, Instituut voor Algemene literatuurwetenschap, Rijksuniversiteit van Utrecht.

VAN COLLER, H.P. en M.C.J. VAN RENSBURG. 1982. Van mond tot oor. (In: Van Jaarsveld, G.J. red. Wat sê jy? Studies oor taalhandeling in Afrikaans. Johannesburg. McGraw-Hill, pp. 213-233).

VAN COLLER, H.P. 1982. Pilatus of Pilaar. 'n Ondersoek na illokusieverwagtings van De onruszaaier deur Willem van Maanen. (In: Van Jaarsveld, G.J., red. Wat sê jy? Studies oor taalhandeling in Afrikaans. Johannesburg, McGraw-Hill, pp. 235-25l).

VAN COLLER, H.P. 1983. Enkele opmerkinge rondom die begrip 'literêr'. Tydskrif vir Geesteswetenskappe. 23(2): 103-112, Junie.

VAN.JAARSVELD, G.J. (red). 1982. Wat sê jy? Studies oor taalhandelinge in Afrikaans. Johannesburg. McGraw-Hill.

VAN VONDEREN, JOSÉ. 1981-1982. Romansupplementen; een onont gonnen gebied van de productieve receptie. Spektator, nr. 3. pp. 193-211. 
VAN ZOEST, AART. 1978a. Periciaanse Semiotiek. (In: Grivel, Charles, red.: Methoden in de literatuurwetenschap. pp. 102-114. Muiderberg. Coutinho.

VAN ZOEST, AART. 1978b. Semiotiek. Over tekens, hoe ze werken en wat we ermee doen. Baarn. Ambo.

WIEHAHN, RIALETTE, 1965. Die Afrikaanse poësiekritiek; ' $n$ historiesteoretiese beskouing. Kaapstad. Academica. 